Petter Asp, Carl Erik Herlitz \& Lena Holmqvist (red.): Flores juris et legum, festskrift til Nils Jareborg. Iustus Förlag 2002. ISBN 91-7678-487-8. 786 pp.

Festskriftet er en omstridt genre, særlig fordi de enkelte bidrag ofte er indbyrdes heterogene, men det foreliggende eksemplar er usædvanlig vellykket, hvorfor man kan takke, udover naturligvis redaktion og forfattere, den eneste, som ikke har skrevet et ord i bogen selv, nemlig modtageren Nils Jareborg, hvis imponerende oeuvre har inspireret mange af forfatterne ikke blot til den obligate hyldest og gratulation, men også til debat med ham, i flere tilfælde endog til kritisk dialog. Ved i så høj grad at forholde sig til Jareborgs produktion, fra den gamle afhandling Handling och uppsåt fra 1969 til den store sammenfatning Allmän kriminalrätt i 2001, men hvor også hans mindre værker huskes som f.eks. hans analyse Opera och allmän rättslära fra 1990 (p. 591, Henrik Tham), har værkets 46 bidrag derfor fået en i forhold til andre festskrifter homogen karakter.

Værkets betydelige spændvidde viser rigdommen og mangfoldigheden i den strafferetlige tænkning og forskning i Norden, selvom man ikke må glemme de vægtige bidrag fra ikke-nordiske forfattere, særlig tyske, blandt hvilke jeg på dette sted vil fremhæve Nordens bedste ven i det tyske strafferetlige milieu, Karin Cornils, som har bidraget med en grundig sammenstilling mellem principper for sanktionsvalg i Sverige - med særligt henblik på det nye begreb "straffvärde" - og Tyskland; fodnoterne viser påny Jareborgs indflydelse, her inddrages hans skrifter om defensiv og offensiv strafferetspolitik og om neoklassicismen. Det er urimeligt at fremdrage enkelte blandt de mange, ofte lange artikler og at omtale flertallet i telegramstil, men medens jeg er i det tyske, vil jeg fremhæve Winfried Hassemer: "Staat, Recht und Sicherheit in der Informationsgesellschaft" som et af de mest tankevækkende. Overbevisende udlægges, hvordan staten ikke længere er den Leviathan, som det liberale borgerskab skal beskytte sig imod, men den hjælper, som skal hindre skade og forbrydelser helst inden de sker; retten til sikkerhed er blevet en Grundrecht (p. 297 f.); Big Brother indgyder ikke mere frygt, "jetzt hat er bunte Kleider an (oder gar keine)". Netop dette bidrag smager af foredragstonen, en velgørende afveksling ved læsning af tyske akademiske artikler.

Der er mange nordiske ikke-svenske bidrag. Fra Danmark er der halvfjerde bidrag; af Vagn Greve en uhyre grundigt dokumenteret studie om straffuldbyrdelsens mål, inspireret af den nye straffuldbyrdelseslov; af Jørn Vestergaard en stor artikel om det sagkyndige bevis og problemerne ved, at de tekniske sagkyndige bevæger sig ind på en egentlig bedømmelse af skyldspørgsmålet - kan det overhovedet undgås?; af Gorm Toftegaard Nielsen en tankevækkende artikel om kvinder, som ved ikke at gribe ind over for deres mands grove vold over for deres børn ifølge retspraksis gør sig skyldige i medvirken til vold, og hvor jeg med forf. ville foretrække straf for vanrøgt; endelig af Per Ole Träskman \& Britta Kyvsgaard en stor fælles artikel, på svensk, men om et dansk emne, skiftende politiske forsøg på styring af strafudmålingen, først i nedadgående, senere dramatisk i skærpende retning.

Fra Norge er der tre bidrag; af den dybt savnede. alt for tidligt afdøde Svein Slettan en indtrængende advarsel imod overhåndtagende kriminalisering, sluttende med et effektfuldt citat fra Sigurd Hoel i anden sammenhæng, men af god relevans "Skjær bort alt overflødig. Flere ting er overflødigere enn du gjerne vil tro", en artikel, som bør læses jævnsides med de "visionära funderingar" af Erland Aspelin om begrænsning af kriminaliseringen og Henrik Thams overvejelser om, hvorvidt forbryderen er vinder eller taber $i$ den moderne kriminalpoltii, bl.a. med omtale af noget så kættersk som abolitionismen 
(p. 591); af Sture Eskeland en påpegning af, at strafferet også bør beskæftige sig med de største spørgsmål som brug af kernevåben; af Magnis Matningsdal \& Asbjørn Strandbakken en uhyre grundig gennemgang af Høyesteretts forsøg på at styre især strafudmålingen, som bør læses jævnsides med Dag Victors fyldige gennemgang af svensk Högsta Domstolens forsøg på at begrænse sin virksomhed til præjudikatdannelse og af især de mange sager om sanktionsvalg med særlig vægt på spørgsmålet om anvendelsesområdet for samfundstjeneste, også i Danmark et spørgsmål, som har medført mange højesteretssager.

Men fra Finland er der hele otte bidrag, med rette efter de århundredgamle forbindelser mellem de to østnordiske lande. I disse tider må læseren næsten være taknemmelig for, at kun to af de otte har skrevet på engelsk, de andre på svensk; man må håbe på, at de nordiske sprog velbliver at være de naturlige redskaber for nordiske akademikere. Alle nævnt, ingen glemt: Kun halvfjerde side af Eero Backman med provokerende - selv kalder han dem dumme og usystematiske - bemærkninger om idrætsvold; en grundig sammenligning af Dan Frände mellem tysk teori, særlig Roxin, og det af Jareborg skabte begreb "gärningsculpa"; af Raimo Lahti en drøftelse af problemet om strafansvar på andres vegne med udgangspunkt i den stadig pågående totalrevision af den finske straffelov; af Tapio Lappi-Seppälä en grundigt dokumenteret omtale af proportionalitet og andre kriterier for strafudmåling, herunder om forsøgene på at styre udmåling gennem nøje bestemmelser i loven; af Martti Majanen en drøftelse af et nyt forslag om nødværge, hvor det påtænkes at lovfæste den tilsyneladende længe i praksis anvendte interesseafvejning (p. 461); af Jussi Matikkala en neddykning i de forskellige forsætsformer, par excellence et af Jareborgs hovedemner, med den lidt mystificerende titel "Att tro att $\mathrm{p}$. Om avsiktlighetsuppsåt”, hvor også det fra Vestnorden kendte sandsynlighedsforsæt inddrages i drøftelserne; af Kimmo Nuotio en vision om en forventelig uhyre vidtgående europæisering af strafferetten, ikke blot svarende til det måske kuldsejlede corpus jurisprojekt (p. 551), men dækkende langt flere områder, jfr. opregningen p. 550; endelig af Ari-Matti Nuutila det jordnære spørgsmål, om forbryderen ved at fortie sit udbytte for skattevæsenet gør sig skyldig i en selvstændig skattelovsovertrædelse - der er ikke grænser for skattemyndighedernes grådighed - med særligt henblik på den europæiske menneskerettighedskonventions forbud mod en pligt til selvinkriminering.

Den hyppigst behandlede emnekreds er sanktionsvalg, særlig strafudmåling, ganske tankevækkende for den danske recensent $\mathrm{i}$ lyset af, at netop strafudmåling traditionelt hos os betragtes som hidrørende under dommerskønnet, som i lige grad unddrager sig teoriens analyse, bortset fra von Eybens gamle disputats om strafudmåling fra 1950, og lovgiverens forsøg på nøjere påvirkning, medens forsøgene på politisk styring udefra set synes langt mere gennemgribende i Sverige og Tyskland. Udover de tidligere nævnte Cornils, Lapp-Seppälä, Matningsdal/Strandbakken, Träskman/Kyvsgaard, Victor - er det følgende: Endnu et tysk bidrag af Wolfgang Frisch, som modstiller skærpende og formildende omstændigheder efter svensk ret - hvor han har nydt godt af en væsentlig tysksproget artikel af Jareborg - og tysk ret. Meget er lig, men der er store forskelle, hvoraf en af de væsentligste er, at ikke blot selvanmeldelsen, men også den blotte tilståelse, selv fra den alligevel afslørede, er en formildende omstændighed efter tysk ret, men ikke efter svensk (og dansk) ret (p. 217). Hovrättslagman Martin Borgekes gennemgang af hovedprincipperne på sanktionsfastsættelse med påvisning, at lovgivers intentioner ikke altid (kan) følges i retspraksis. Redaktøren Lena Holmqvists artikel med den konci- 
se overskrift "Hur mycket", hvor hun - med udgangspunkt i arbejder af Jareborg skildrer bl.a. forbrydelsers rangordning, herunder den vanskelige grænse mellem forsæt og uagtsomhed (p. 337 ff.). To bidrag om specielle strafnedsættelsesgrunde, Johan Munck om det måske mest (kun?) teoretiske spørgsmål om, hvorvidt ung alder allerede påvirker forbrydelsens "straffvärde" eller først kommer efterfølgende i betragtning, og Andrew von Hirsch om "social deprivation" som en særlig nedsættelsesgrund i lyset af det generelle proportionalitetsprincip - forf. er dog klar over, at det vil være næsten umuligt at gennemføre i praksis; hvis forbrydelsen X objektivt anses som mere alvorlig end $\mathrm{Y}$ og derfor som udgangspunkt skal straffes strengere, men X ofte(st) begås af de mest "deprived", vil en sådan nedsættelsesgrund medføre en udviskning af forskellen mellem X og Y (p. 329). Jeg finder selv, at hvis en nedsættelsesgrund kan påberåbes af næsten alle, bliver den umulig at anvende. Martin Wasik påviser i en lille artikel med den morsomme titel "Can We Rely on the Past?" fejl og unøjagtigheder ved udarbejdelse af strafattester, hvilket kan have ødelæggende betydning for sanktionsfastsættelsen i systemer, hvor tidligere straffe medfører strengere sanktion i den aktuelle sag; man må håbe og formentlig tro - at registrene føres bedre i Norden end i England, som forf. skildrer. I øvrigt må jeg som praktiker anbefale, at hvis dommeren vil tillægge tidligere domme betydning for udmålingen, bør han ikke lade sig nøje med straffeattesten, men læse de relevante domme. Håkan Westin påviser i "Påföljd utan ansvar", at sanktioner, som ikke anses som straf, desuagtet kan opfattes som og virker på samme måde som frihedsberøvende straffe, og at det strafferetlige legalitetsprincip ikke altid (kan) opfyldes, når de bringes $i$ anvendelse.

Strafferettens internationalisering og særlig europæisering er en anden emnekreds, som har tiltrukket flere forfattere. Udover Eskeland og Nuotio er det følgende: Iain Cameron med en uhyre grundig og veldokumenteret gennemgang af svensk straffelovs muligheder for at ramme handlinger begåede uden for Sverige; med særlig interesse læste jeg gennemgangen af sagen om et "æresdrab" begået i irakisk Kurdistan, hvor ofret var en i Sverige domicileret ung kvinde, og hvor det lykkedes at gennemføre en straffesag i Sverige (p. 140 f.). Mireille Delmas-Marty, en af hovedarkitekterne bag corpus juris, som tankevækkende gør gældende, at selvom harmonisering af nationale regler kan være mere ønskværdig for de enkelte stater, indebærer det sådanne vanskeligheder, at en egentlig "unification", endog med fælles myndigheder, d.v.s. en europæisk anklagemyndighed, om end ikke (læseren fristes til at spørge "endnu?") en europæisk straffedomstol (p. 179 ff.). Hans G. Nilsson, som fra sin post i Bryssel som afdelingschef ved EU's retlige samarbejde skildrer de praktiske vanskeligheder ved det internationale samarbejde imod organiserede forbrydelser - undertitlen "the Titanic scenario" viser den pessimistiske holdning. Rättschef i det svenske justitiedepartement Fredrik Wersäll, som ud fra erfaringerne med det svenske formandskab i 2001 skildrer samspillet mellem politik og jura i europæiseringen af strafferetten, lidt mere optimistisk end Nilsson.

Spørgsmål om meddelagtighed, ansvar for andres handlinger etc. behandles udover af Lahti og Toftegaard Nielsen af tre svenske bidrag, som supplerer hinanden vel: Den praktiske anklager Peter Lundkvist underkaster den gældende lære om muligheden for at delegere strafansvar en grundig revision og når til det umiddelbart set plausible resultat, at der ikke er tilstrækkelig anledning til at fastholde delegationslæren, idet de ønskede resultater kan nås gennem strafferettens almindelige regler, hvorunder Jareborgs lære om gerningsculpa påny inddrages (p. 448 ff.). Helén Örnemark Hansens "Får man "tackla en 
målvakt"?" handler ikke om idrætsvold, men om vanskelighederne ved at ramme bagmændene for økonomiske forbrydelser og vanskelighederne ved at fokusere opmærksomheden på "målvakten", d.v.s. den synlige stråmand. Et af de mest tankevækkende bidrag i hele værket er Suzanne Wennberg om virksomhedslederens ansvar for overtrædelser begåede i virksomheden, hvor hun efter omhyggelig gennemgang af konkrete sager påviser, efter min opfattelse aldeles overbevisende, hvorledes formentlig uskyldige dømmes med direkte tilsidesættelse af det strafferetlige legalitetsprincip; i virkeligheden straffes de pågældende for, at de ikke aktivt hindrer andres overtrædelser, hvilket er at drage ansvaret alt for vidt. Fra min egen praksis kan jeg supplere med mit ikke-sjældne ubehag over for den uhyre vidtgående kriminalisering af særlig arbejdsgivere i sager efter arbejdsulykker.

De mest retsfilosofiske emner berøres af særlig udenlandske bidragsydere. Skotten Antony Duff - som beklager at være en af de "monoglot Anglophones", som ikke kan læse Jareborg på originalsproget - drøfter kriminaliseringsbegreberne, et af Jareborgs grundbegreber. Douglas Husak drøfter ligeledes kriminalisering med henblik på en nødvendig begrænsning af området for strafsanktioner med udgangspunkt i Jareborgs begreb om en defensiv kriminalpolitik. Oxfordprofessoren John Gardner forsøger sig i "In Defence of Defences" med den vanskelige distinktion mellem "justification" og "excuse". Tyskeren Heike Jung forsøger at få os udlændinge til at forstå meningen med det særlige tyske "Straftatlehre"; jeg kan ikke sige, at jeg savner begrebet på dansk. Endelig går Josef Zila løs på den kollektivistiske og den radikale "brottsideologi" - det er næsten overflødigt at tilføje, at også han er i debat med Jareborg.

De resterende forfattere kan ikke sættes i bås. Veteranen Alvar Nelson gennemgår den særlige svenske nyskabelse "Brottsofferfonden" og sammenligner det med det frit opfundne fabeldyr "skvadern", som ikke burde kunne flyve, men gjorde det alligevel. Sten Heckscher argumenterer kortfattet og efter min mening overbevisende, for en genindførelse af det ved Brottsbalkens gennemførelse afskaffede tilregnelighedsbegreb. Tre forfattere behandler emner fra Speciel Del: Kerstin Berglund anskuer voldtægt feministisk. Redaktøren Petter Asp drøfter ud fra en bizar sag om fangevogteren, som hævede ekstrabetaling for ikke udført arbejde (p. 24), det uhyre vanskelige emne om bedrageri ved udnyttelse af en vildfarelse, som gerningsmanden ikke har skabt selv, og hvor dansk ret synes mere vidtgående end svensk (p. 39). Madeleine Leijonhufvud behandler i "Makt och ansvar - något om de straffrättsliga gränserna för offentligt maktmisbruk" det pinlige faktum, at offentlig forvaltning måske ikke mere er så selvfølgelig hæderlig som i det nostalgiske eksempel om statsminister Erlanders enke, som efter sin mands død afleverede de staten tilhørende blyanter i kanslihuset (p. 432). De sidste to forfattere kommer delvis ind på samspillet mellem strafferet og straffeproces: Andrew Ashworth drøfter de nyeste tendenser i praksis efter den europæiske menneskeretskonvention jeg noterede bl.a., at beskyttelse af forurettede og vidner nu også indgår i Strasbourgdomstolens praksis; artiklen nævner Doorson-dommen (p. 15), men den svenske Lindqvist-dom om videoafhøring af børn viser også, at det er legitimt at tage hensyn til disse svage parter, også selvom det berører den sigtedes retsbeskyttelse. Sluttelig fører HansGunnar Axperger os à jour med det vanskelige spørgsmål om "brottsprovokation", begyndende med Eva og slangen og endende med "en nämndemannadom, som förtjänar herostratisk ryktbarhet” (p. 76) efter et groft eksempel på politiprovokation.

Alle nævnt, ingen glemt, men igen, en væsentlig grund til dette statelige festskrifts 
styrke er, at der udover de 46 fortjenstfulde forfattere er den syvogfyrretyvende i Jareborg selv, i stadig og frugtbringende dialog med hans kolleger i ind- og udland.

\section{Peter Garde}

Hillerød kriminalret

\section{Ralph J. Henham: Sentence Discounts and the Criminal Process. Ashgate Dartmouth 2001. 115s. + bilag.}

Bogen handler om strafnedsættelse i tilståelsessager ved engelske domstole. Ligesom i nordiske lande hersker der også i England og Wales delte meninger om tilståelse har og bør have strafnedsættende effekt; og ligesom i nordiske lande er der delte meninger om det såkaldte plea-bargaining institut, hvorefter tilståelser opnås igennem en nedsættelse af den forventede straf. Bogens konkrete udgangspunkt er Criminal Justice and Public Order Act af 1994. I dennes sec. 48 blev det lovfæstet, at retten ved straffastsættelse for en dømt som har tilstået det kriminelle forhold tidligere i sagen, dels skal tage det tidspunkt i processen hvor den dømte indikerede sin ambition om at tilstå, og dels omstændighederne hvorunder tilståelsen blev givet, i betragtning. Det centrale herved er for det første, at tilståelse er strafnedsættende, men for det andet at også tidspunktet for og omstændighederne ved tilståelsen er af relevans. Det fulgte ydermere af bestemmelsen, at hvis retten tildeler en reduktion ved straffastsættelsen på grund af en tilsåelse, skal dette udtales i sagen. Bogens hovedærinde er at undersøge om og i hvilken udstrækning engelske domstole faktisk følger principperne i denne 1994 Acts sec 48.

Bogen består af tre dele. I første del foretager forfatteren en empirisk afdækning af anvendelsen af principperne i sec. 48 i Crown Courts. Undersøgelsen er baseret på 310 sager fra seks udvalgte Crown Courts, dækkende perioden april til september 1997. Det anvendte materiale består af samtlige dokumenter og notater fra domsforhandlingerne i hver sag. Undersøgelsens centrale resultat er, at bestemmelsen om strafnedsættelse for tilståelse i vid udstrækning ikke anvendes. I næsten $50 \%$ af de 310 tilståelsessager angiver dommeren end ikke en strafnedsættelse og i $50 \%$ af alle sager angives det stadie som en tilståelse er givet på, som mindre eller af ingen betydning overhovedet for straffastsættelsen. Derudover viser undersøgelsen, at i de sager hvor der er angivet en strafnedsættelse, er det kun i $17 \%$, at der er givet en begrundelse i retten. Disse resultater viser med tydelighed, at bestemmelsen i vid udstrækning ikke anvendes og i særlig grad ikke lever op til kravene om begrundelse. Derudover er det interessant, at forfatteren ved at sammenligne de seks Crown Courts finder store variationer mellem de enkelte domstoles iagttagelse af sec. 48 .

I bogens anden del udstrækkes den empiriske undersøgelse til to magistrates' courts. Som forfatteren forklarer, er tilståelse den almindelige fremgangsmåde ved disse retter og det er derfor særligt interessant hvordan tilståelser afspejles i strafnedsættelser her. Der er til undersøgelsen anvendt spørgeskemaer, uddelt til og returneret af de enkelte magistrates' courts, som i en to ugers periode i april 1998 udfyldte spørgeskemaerne i forbindelse med behandlingen af de daglige sager. Undersøgelsen viser, at i $90 \%$ af tilståelsessagerne ved de to magistrates' courts havde tilståelse en positiv effekt på strafnedsættelsen. Ydermere, i over $65 \%$ af sagerne fandtes stadiet hvorpå tilståelsen var givet, at være af betydning for strafnedsættelsen. Hvad angår størrelsen af strafnedsættel- 
se viser undersøgelsen, at i $33 \%$ af sagerne tildeltes der over en tredjedel strafnedsættelse. Dette er en kraftig overstigelse af det konventionelle niveau (s83-). Ikke overraskende fandtes det stadie som tilståelsen er givet på, at have en større rolle i disse sager end i andre. Undersøgelsen viser visse forskelle mellem de to magistrates' courts; dels i størrelsen af strafnedsættelse (s83) og dels i den betydning som tilståelse tillægges i sager med henholdsvis høje og lave strafnedsættelser (s86). Det er derudover ikke uden interesse, at undersøgelsen viser en positiv sammenhæng mellem tilståelsers effekt på beslutningen om at idømme ubetinget frihedsstraf eller en alternativ sanktion og så om magistraten har modtaget vejledning af 'the court clerk' om straffastsættelse.

En fælles konklusion på disse undersøgelser er, at de generelle principper om strafnedsættelse for tilståelse i vid udstrækning ikke anvendes og når de gør, anvendes med stor variation imellem sager og imellem domstole. Selvom undersøgelsernes materialer gør en sammenligning vanskelig, er det bemærkelsesværdigt, at de hyppige tilståelser i de travle magistrates' courts sammenlignet med de seks Crown Courts, synes at blive tillagt større strafnedsættende betýdning. Henham finder det på grundlag af de to undersøgelser problematisk, at der er så ringe overblik over hvilke faktorer som domstole skal lægge vægt på ved strafnedsættelser og at der er en lav gennemsigtighed i beslutningsprocessen. Bogens sidste del tager fat om disse problemer. Forfatteren foretager en sammenligning af strafnedsættelse og retlig styring heraf i U.S.A. og i England og Wales. Han argumenterer for, at U.S. amerikanske state guideline systemer kan tjene som paradigme for styring af strafnedsættelse ved engelske domstole; dels som middel til at skabe større ensartethed i strafnedsættelse, dels som middel til at rationalisere strafnedsættelsesprocessen. Konkret foreslår han, at de gældende engelske regler revideres, så at de opregner de strafnedsættende faktorer som domstole skal tage i betragtning, samt at der indføres et guideline system til sikring af at domstole angiver størrelsen af strafnedsættelser og begrundelserne for strafnedsættelser.

Bogens tre dele udgør hver især det væsentligste af tidligere offentliggjorte artikler af forfatteren. Tanken med at præsentere dem samlet i bogen er i en udgivelse at dokumentere hvordan principperne om strafnedsættelse i tilståelsessager anvendes (bogens del et og to), identificere problemer ved anvendelsen og fremlægge mulige løsninger på problemerne (bogens del tre). Bogen er præget af mange interessante resultater og vigtige iagttagelser, men også af at det ofte er svært at få øje på den gennemgående røde tråd. Bogen er rigt illustreret med let overskuelige tabeller, som det, til trods for bogens fyldige bilag, til tider er svært at gennemskue det empiriske grundlag for.

Hvis man som jeg, forventer analyser af den faktiske strafnedscettelse når forfatteren angiver at ville undersøge empirisk hvordan principperne om strafnedsættelse i tilståelsessager anvendes, bliver man temmelig overrasket, særligt over bogens første del. Det er nemlig $i k k e$ den faktiske strafnedsættelse eller den faktiske sammenhæng mellem tilståelse og andre af sagens forhold som forfatteren undersøger, men derimod hvad domstolen noterer derom under sagen. Det er f.eks. ikke en 30 dages lavere straf som er iagttaget empirisk, men domstolenes angivelse af at der er givet nedsættelse i straffen. De to ting er ikke nødvendigvis overensstemmende og det ville derfor have været en hjælp om forfatteren havde gjort dette klarere fra starten. Det er nemlig bestemt ikke en mindre interessant undersøgelse af den grund: I stedet for at være en empirisk undersøgelse af faktisk strafudmåling, er det snarere en undersøgelse den lokale retspraksis ved enkelte domstole. 
Selvom bogens fokus er en konkret engelsk retsregel kan undersøgelsen også være af interesse for nordiske læsere. Særligt findes der for det første ikke mange empiriske undersøgelser af domstoles lokale anvendelse af retsregler. Den stadige påmindelse af at der er forskel mellem skreven og anvendt regel er værdifuld i sig selv. For det andet kan det tænkes, at specielt bogens første del kan inspirere til hvordan man kan undersøge i hvilken udstrækning domstole implementerer gennemført lovgivning. Ligesom i England, er nordiske lande også i disse år påvirket af en stærk bevægelse mod større styring og kontrol med domstoles strafudmåling. Denne bevægelse afføder bl.a. et behov for at kunne undersøge i hvilken udstrækning styring og kontrol med domstolene virker efter hensigten. Særligt bogens første del kan tages som et eksempel på sådanne undersøgelser. Selvom de ikke fortælle noget om hvordan den faktiske strafudmåling påvirkes, fortæller den i hvilken grad de enkelte domstole tager den retlige styring til sig.

\section{Rasmus H. Wandall}

Københavns Universitet

Zygmunt Bauman \& Tim May: At toenke sociologisk. Hans Reitzels Forlag, København 2003, 272 s.

Baumans sociologiske introduktionsbog "At tænke sociologisk" fra 1990 er udkommet i en ny udgave. Anden udgaven er en udvidet og fuldstændig revideret udgave af det oprindelige oplæg. Det er Tim May, der har stået for den nye udgave, men selvom pennen er ført af May, aner man stadig Baumans karakteristiske stil på de 272 sider, der forsøger at indføre læseren i den sociologiske videnskabs teoretiske grundlag. Indledningsvis giver forfatterne en kort introduktion til faget sociologi og den særlige betragtningsmåde, som sociologien gør brug af. I denne forbindelse behandles forholdet mellem common sense viden og sociologien. Introduktionen peger blandt andet på, hvorfor de erkendelser og konklusioner, som sociologien fremkommer med, ofte kan virke forstyrrende og endog foruroligende, fordi de netop sætter spørgsmålstegn ved den virkelighed, som vores dagligdags common sense forståelser er forankret i. Allerede her er forfatternes tilknytning til og inspiration fra den kritiske teori således ganske tydelig.

I modsætning til mange andre grundbøger inden for det sociologiske felt, der ofte er struktureret omkring teorier og teoriretninger, er denne introduktion tematisk ordnet. Bogen er inddelt i 3 dele. Første del udgøres af 3 kapitler, der beskæftiger sig med: "Handlen, identitet og forståelse i dagligdagen". De 3 kapitler behandler centrale sociologiske temaer som gruppetilhørsforhold, identitet, interaktion, socialisering, symbolsk kommunikation, den anden/den fremmede, social segregation og bylivet. Anden del består af 6 kapitler under overskriften: "Om at leve vort liv: Udfordringer, valg og tvang". De 6 kapitler sætter fokus på en lang række områder, som sociologien i tidens løb har interesseret sig for. Det drejer sig om magt og moral, gaver, bytte og kærlighed, krop, sundhed og seksualitet, tid, rum og (u)orden, kultur, natur, stat og territorium samt forbrug, teknologi og livsstil. Tredje del består af kapitlet: "At tænke sociologisk", hvor trådene samles, og hvor forfatterne giver deres endelige bud på sociologiens genstandsfelt og særlige blik samt af en række spørgsmål til de enkelte kapitler og forslag til videre læsning om de forskellige temaer, der behandles i bogen.

Bauman og Mays introduktion til sociologien er velskrevet og læsværdig, om end den 
næppe rummer nogle overraskelser for personer, der allerede har beskæftiget sig indgående med den sociologiske videnskab. Som grundbog er den anvendelig også uden for universiteterne blandt andet fordi mange af de temaer, der tages op i bogen, må siges at være relevante for en lang række faggrupper som for eksempel lærere, pædagoger, socialrådgivere, sundhedspersonale, politifolk og andre, der til dagligt arbejder med mennesker.

Anne-Stina Sørensen

Københavns Universitet 